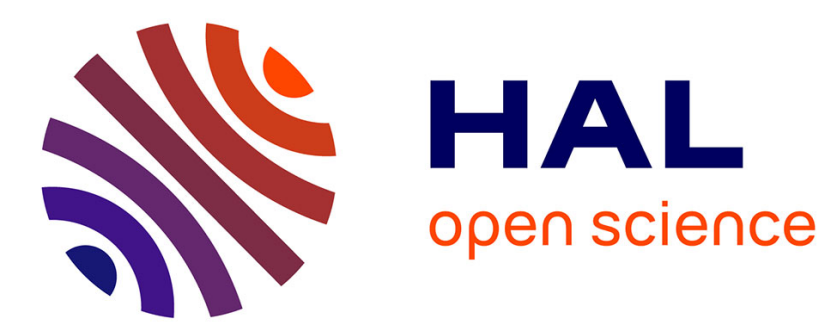

\title{
Strategizing for Production Innovation
}

David Romero, Lisa Larsson, Anna Öhrwall Rönnbäck, Johan Stahre

\section{To cite this version:}

David Romero, Lisa Larsson, Anna Öhrwall Rönnbäck, Johan Stahre. Strategizing for Production Innovation. IFIP International Conference on Advances in Production Management Systems (APMS), Sep 2017, Hamburg, Germany. pp.3-12, 10.1007/978-3-319-66923-6_1 . hal-01666209

\section{HAL Id: hal-01666209 \\ https://hal.inria.fr/hal-01666209}

Submitted on 18 Dec 2017

HAL is a multi-disciplinary open access archive for the deposit and dissemination of scientific research documents, whether they are published or not. The documents may come from teaching and research institutions in France or abroad, or from public or private research centers.
L'archive ouverte pluridisciplinaire HAL, est destinée au dépôt et à la diffusion de documents scientifiques de niveau recherche, publiés ou non, émanant des établissements d'enseignement et de recherche français ou étrangers, des laboratoires publics ou privés.

\section{(c)(1)}

Distributed under a Creative Commons Attribution| 4.0 International License 


\title{
Strategizing for Production Innovation
}

\author{
David Romero ${ }^{1-3}$, Lisa Larsson ${ }^{2}$, Anna Öhrwall Rönnbäck ${ }^{2}$, Johan Stahre ${ }^{3}$ \\ ${ }^{1}$ Tecnológico de Monterrey, Mexico \\ david.romero.diaz@gmail.com \\ ${ }^{2}$ Luleå University of Technology, Sweden \\ lisa.larsson@Itu.se, anna.ohrwall.ronnback@Itu.se \\ ${ }^{3}$ Chalmers University of Technology, Sweden \\ johan.stahre@chalmers.se
}

\begin{abstract}
Manufacturing firms are constantly evolving to accommodate new customer requirements as well as emerging technologies, materials, processes and equipment. As a consequence, a broad range of production innovation opportunities arise for manufacturing firms to produce their products in smarter, more flexible, agile and sustainable ways. This paper proposes a strategic planning framework for "production innovation" and discusses its implications for the evolution of companies-specific production systems and competitive advantages.
\end{abstract}

Keywords: Production Innovation, Process Innovation, Production Capabilities, Manufacturing, Competence, Readiness Levels, Maturity.

\section{Introduction}

Production Innovation [1] is a concept describing on-going re-engineering processes and a core-organisational culture in itself. It aims to evolve product and production engineering from prevalent trends of 'continuous improvement' towards 'continuous innovation'. This, in order to retain and emphasize the competitive advantage of any manufacturing firm by adopting and developing the next generation manufacturing and processing technologies as well as working methods ahead of competition. Production Innovation involves constant monitoring and evaluation of the advances in research and technology development in the areas of production management systems and related technologies and working methods. This also includes the assessment of such technologies and working methods readiness for adoption at the shop-floor. Moreover, production innovation considers the upgrade and/or renewal of the 4M (man, material, machine and method) in order to strengthen the productivity and resource efficiency of a production system.

This paper proposes a strategic planning framework for "production innovation" based on the identification, development, integration and adoption of the appropriate production, organisational and financial capabilities, at their proper readiness level, in a manufacturing firm's shop-floor. The goal is to not just enable a new manufacturing competence or to bring an existing one to its next level within a manufacturing firm, but also to support the maturing (mastering) of such new or improved manufacturing competence.

This initial research work was developed based on a literature review and interviews with academic and industrial experts in advanced production management systems. 


\section{Basic Concepts}

An underlying concept, Process Innovation [2] refers to implementation of a new or significantly improved production or delivery method (including significant changes in techniques, equipment and/or software) in order to acquire a new or increase a current production or service capability in a manufacturing or logistical system, which must lead to added value for the firm (company value) and its value chain (value chain value).

Within the definition of process innovation, company value is defined as the benefits perceived from a process innovation by the different departments of a manufacturing firm (inner-added value). Value chain value is defined as the benefits perceived from that same process innovation by the members of a manufacturing firm's value chain due to its increase of company value (inter-added value). This could be in terms of e.g. saving time, reducing risks, reducing costs, improving quality, increasing variety, reducing efforts or simplifying, organising, integrating and connecting things, etc. In the end, it is about creating positive environmental, economic and social effects in the operating model of a manufacturing and/or logistical system at intra- and interorganisational level.

Furthermore, a production capability (also called 'manufacturing capability') must be understood as a unique combination of tools, materials, methods and people engaged in producing a measurable output within the framework of technical, physical and financial limitations of a manufacturing firm. Since 'production capabilities' require people, 'organisational capabilities' for innovation in a manufacturing firm must be also considered in order to realize a 'production innovation'. Organisational (workforce) capabilities refer to socially complex routines determining the effectiveness | efficiency with which manufacturing firms ( $c f$. their workforce) can transform learning and knowledge into actionable operational working methods. Moreover, the development of production and organisational capabilities in a manufacturing firm relies on its financial capabilities. This encompasses knowledge, attitudes, skills and behaviours of their stakeholders with regards to the required investment, and available financial instruments to invest in production equipment (technology) acquisition and education/ training programs (workforce).

In this sense, production innovation may be defined as the process of developing or increasing a production (manufacturing) capability together with the manufacturing firm's organisational (workforce) capabilities by implementing new production equipment and deploying a new working method for it in a production environment (see Fig. 1). Intended effects are company and value chain value.

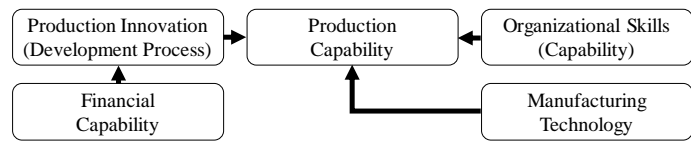

Fig. 1. Elements Influencing Production Capability and its Development

It is argued that a production innovation could be seen as a 'socio-technical endeavour' (e.g. an engineering project). From a technical perspective, production capabilities for innovation are required to develop new or improve current production equipment, and from a social perspective, organisational capabilities for innovation, such as the absorptive capability of a manufacturing firm, are needed to learn and master the use of such new production equipment and their related working method(s). 


\section{Strategizing for Production Innovation}

To strategically work on 'production innovation' initiatives, it means to develop new or improve existing manufacturing competences in a firm based on the convergence of appropriate readiness levels of manufacturing technology, workforce skills and knowledge, and financial resources to invest in a production innovation project.

A (generic) production innovation project aims to acquire new or upgrade current production equipment, and to train the workforce in its use (working method), for achieving a new or defending an existing competitive advantage.

In a production innovation process (i.e. a project), two main challenges can be identified for a manufacturing firm: (a) how to achieve alignment between Manufacturing, Organisational and Financial capabilities (MOF capabilities) in a specific moment in time, i.e. a workforce with the willingness to learn and use new or upgraded production equipment acquired to create value, and (b) once enablers (equipment and workforce) for new manufacturing competence have been acquired, how are these perfected to increase their potential for creating value.

In this paper, the use of readiness levels is proposed as a way to assess the: (a) Readiness of innovative manufacturing technologies and/or working methods to be integrated and brought into a (real) production environment as an added value, (b) Readiness of the workforce to learn and put into systematic practice new skills and knowledge, and (c) Readiness level of the manufacturing firm stakeholders to invest in the production innovation project. The use of readiness levels aim to achieve a reliable decision-making support for stakeholders in regards to the potential to successfully integrate the needed production, organisational and financial capabilities towards 'production innovation', and consequently new manufacturing competence (see Table $1 \& 2$ ) and later on manufacturing competence levels (see Table 3).

Table 1. MOF Capabilities Readiness Levels (RL) [Adapted from 3]

\begin{tabular}{|c|c|c|c|}
\hline RL & Manufacturing Technology [3] & Organisational (Workforce) & Financial Investment \\
\hline 1 & - Manufacturing principle described. & $\begin{array}{l}\text { - Workforce } \\
\text { described. }\end{array}$ & $\begin{array}{l}\text { - Investment on production } \\
\text { innovation project estimated. }\end{array}$ \\
\hline 2 & $\begin{array}{l}\text { - Concept of machinery equipment in } \\
\text { series production described. } \\
\text { - Interaction with material analysed. }\end{array}$ & $\begin{array}{l}\text { - Skills and knowledge related to } \\
\text { the operator competence } \\
\text { described. } \\
\text { - Interaction with equipment and } \\
\text { software analysed. }\end{array}$ & $\begin{array}{l}\text { - Investment on } \begin{array}{r}\text { production } \\
\text { innovation project } \\
\text { described }\end{array} \\
\text { (project roadmap). } \\
\text { - Production innovation project } \\
\text { ROI analysed. }\end{array}$ \\
\hline 3 & 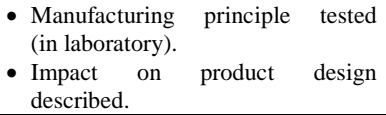 & $\begin{array}{l}\text { - Working method tested } \\
\text { (in laboratory). } \\
\text { - Impact on workstation } \\
\text { described. }\end{array}$ & $\begin{array}{l}\text { - Investment on production } \\
\text { innovation project approved. } \\
\text { - Budget for production innovation } \\
\text { project detailed. }\end{array}$ \\
\hline 4 & $\begin{array}{l}\text { - Technology capability proven. } \\
\text { - Material proven. }\end{array}$ & $\begin{array}{l}\text { - Working method capability } \\
\text { proven. } \\
\text { - Skills and knowledge proven. } \\
\end{array}$ & $\begin{array}{l}\text { - Suppliers for manufacturing } \\
\text { technology and workforce } \\
\text { education and training identified. }\end{array}$ \\
\hline 5 & $\begin{array}{l}\text { - Concept of plant and production } \\
\text { line designed (including capacity } \\
\text { planning). } \\
\text { - Suppliers identified. }\end{array}$ & $\begin{array}{l}\text { - Working method designed. } \\
\text { - Education and training needs } \\
\text { identified. } \\
\text { - Suppliers identified. }\end{array}$ & $\begin{array}{l}\text { - Production innovation project } \\
\text { schedule defined. } \\
\text { - Suppliers selected. }\end{array}$ \\
\hline 6 & - Series capability proven. & $\begin{array}{l}\text { - Working method capability } \\
\text { proven. }\end{array}$ & $\begin{array}{l}\text { - Purchases made of equipment. } \\
\text { - Contracts signed for training. }\end{array}$ \\
\hline 7 & - Suppliers and materials certified. & - Workforce certified. & - Full payments due. \\
\hline 8 & $\begin{array}{l}\text { - Low rate production demonstrated } \\
\text { (pilot run). }\end{array}$ & $\begin{array}{l}\text { - Low scale working method } \\
\text { demonstrated (pilot run). }\end{array}$ & $\begin{array}{l}\text { - Production innovation project } \\
\text { ROI demonstrated. }\end{array}$ \\
\hline
\end{tabular}




\begin{tabular}{|c|l|l|l|}
\hline 9 & $\begin{array}{l}\text { Start of (series) production } \\
\text { (job nr. 1). }\end{array}$ & $\begin{array}{l}\text { - Start of working method usage } \\
\text { in the shop-floor. }\end{array}$ & $\begin{array}{l}\text { Production innovation project } \\
\text { ROI demonstrated. }\end{array}$ \\
\hline 10 & $\begin{array}{l}\text { Overall equipment effectiveness } \\
\text { (OEE) at comprehensive level. }\end{array}$ & $\begin{array}{l}\text { Overall labour (working } \\
\text { method) effectiveness (OLE) } \\
\text { at comprehensive level. }\end{array}$ & $\begin{array}{l}\text { Overall investment effectiveness } \\
\text { (OIE) at comprehensive level. }\end{array}$ \\
\hline
\end{tabular}

Furthermore, for supporting the integration process of MOF capabilities, Sauser et al (2010) [4] have proposed an Integration Readiness Level (IRL) scale (see Table 2).

Table 2. MOF Capabilities Integration Readiness Level (Adapted from [4])

\begin{tabular}{|c|l|}
\hline IRL & MOF Capabilities Integration Scale \\
\hline 1 & $\begin{array}{l}\text { - An interface (cf. a production innovation project) between MOF capabilities has been identified with sufficient } \\
\text { detail to allow characterisation of the (cost-benefit) relationship. }\end{array}$ \\
\hline 2 & $\begin{array}{l}\text { - There is some level of specificity to characterise the interaction (i.e. ability to influence) between capabilities } \\
\text { through their interface. }\end{array}$ \\
\hline 3 & $\begin{array}{l}\text { - There is compatibility between MOF capabilities to orderly and efficiently integrate and interact in a } \\
\text { production innovation project. }\end{array}$ \\
\hline 4 & $\begin{array}{l}\text { There is sufficient detail in the quality and assurance of the integration between MOF capabilities. } \\
\text { - There is sufficient control between MOF capabilities necessary to establish, manage and terminate their } \\
\text { integration in a production innovation project. }\end{array}$ \\
\hline 6 & $\begin{array}{l}\text { - The MOF capabilities integration can accept translate and structure information for its intended application } \\
\text { (i.e. production innovation's project definition detailed). }\end{array}$ \\
\hline 7 & $\begin{array}{l}\text { - The MOF capabilities integration has been verified and validated, and an acquisition/insertion decision can } \\
\text { be made (i.e. production innovation project acceptance). }\end{array}$ \\
\hline 8 & $\begin{array}{l}\text { - Actual MOF capabilities integration completed and production innovation project objectives qualified through } \\
\text { test and demonstration in the production system environment. }\end{array}$ \\
\hline 9 & $\begin{array}{l}\text { - MOF capabilities integration is production innovation project objectives achieved through successful } \\
\text { new production system operations. }\end{array}$ \\
\hline
\end{tabular}

Moreover, once new manufacturing competence has been instated at the firm, it will require 'ramp-up' and therefore the mastering of it has a learning curve. Thus, the use of maturity levels is proposed (see Table 3) to rank performance of the manufacturing firm in deploying new manufacturing competence or manufacturing competence level.

Table 3. Production (Manufacturing) Competence Maturity Levels

\begin{tabular}{|c|c|l|}
\hline $\begin{array}{c}\text { Maturity } \\
\text { Levels }\end{array}$ & $\begin{array}{c}\text { Product Innovation } \\
\text { Ramp-Up Stages }\end{array}$ & \multicolumn{1}{c|}{$\begin{array}{c}\text { Production Innovation } \\
\text { Focus per Stage }\end{array}$} \\
\hline 1 & Initial & • Manufacturing competence implemented. \\
\hline 2 & Repeatable & $\bullet$ Manufacturing competence effectiveness at comprehensive level. \\
\hline 3 & Defined & $\bullet$ Manufacturing competence effectiveness achieved according to standards. \\
\hline 4 & Managed & $\bullet$ Manufacturing competence managed in accordance with firm's metrics. \\
\hline 5 & Optimizing & $\bullet$ Manufacturing competence optimized and improved. \\
\hline
\end{tabular}

Fig. 2 introduces the production innovation cube as a strategic planning framework for the identification and integration of the proper MOF capabilities (at their appropriate readiness level), to enable a new or develop an existing manufacturing competence, as well as for the maturity (mastering) of such new or improved manufacturing competence. Also, it depicts the development of manufacturing competence as the integration of production (manufacturing) technology capability, organisational (workforce) - learning - capability and financial - investment - capability to later mature (master) such new acquired competence. 


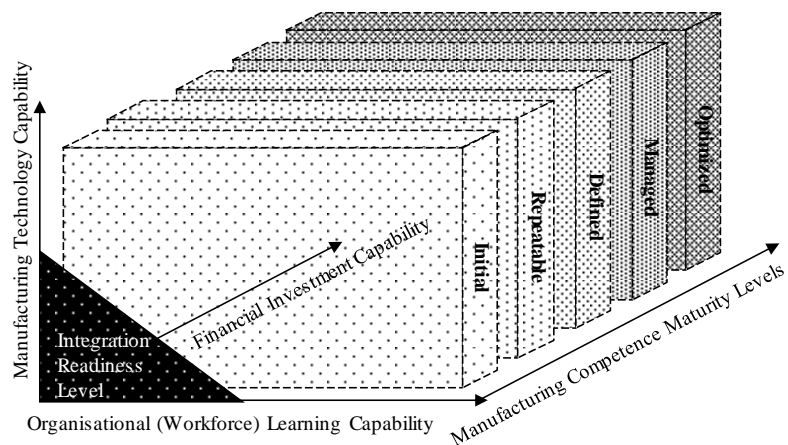

Fig. 2. Production Innovation Cube - A Strategic Planning Framework

\section{A Production Innovation Guide}

The production innovation guide proposed in this paper is composed by three main

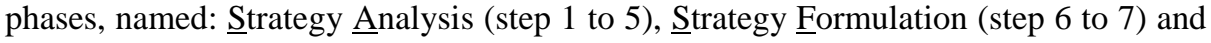
Strategy Implementation (step 8 to 9). Each phase is divided in several steps to be followed by the production manager or production engineer in order to design and justify a production innovation project.

SA/Step 1. Define what drives the necessity for a production innovation project, e.g.:

- Endogenous drivers - A request from other organisational department:

- Management department request for a 'production innovation' to develop a (new) competitive advantage (e.g. cyber-physical production system).

- Human Resources department request for updating/renewing the workforce skills and knowledge in the use of new production equipment (e.g. metal 3Dprinting) or working method (e.g. digital lean manufacturing).

- Technology Development department request for updating and/or renewing production equipment (including software) to develop new manufacturing capabilities (e.g. smart manufacturing system).

- Procurement department request for adopting a new production standard in order to facilitate interoperability of production systems and the integration of these production systems across their value chain (e.g. computer integrated manufacturing / integrated value chain).

- Operations department request for obtaining a new production certification in order to obtain an independent third-party validation and recognition that certifies that its (cyber-physical) production system has passed certain performance, quality and (cyber-)security tests, and meets the qualification criteria stipulated in contracts, regulations, specifications or standards (e.g. Six Sigma, ISO standards).

- Sales department request for production cost reduction to maintain a competitive product price in the market without scarifying quality (e.g. less waste (Muda) - lean manufacturing).

- Marketing department request for production flexibility to offer masscustomization with high quality, low cost and short-delivery time (e.g. flexible manufacturing). 
- Logistics and Distribution department request for production speed to deliver product orders on time and in the required volume, especially in highdemand seasons (e.g. agile manufacturing).

- Customer Service department request for enabling servitization opportunities (e.g. product-service system, internet of things).

- Exogenous drivers - Enforced by competition or legislation:

- Competition enforcing new competitive price, quality and/or delivery time.

- Environmental regulations requesting higher levels of eco-efficiency (e.g. resources consumption and emissions).

SA/Step 2. Describe current production (manufacturing), organisational (workforce) and financial investment capabilities ( $A S$-IS model):

- A production (manufacturing) capability can be described in terms of the ability to perform a manufacturing process within certain production performance parameters, expressed as a manufacturing process capability index $\left(\mathrm{C}_{\mathrm{pk}}\right.$ or $\left.\mathrm{C}_{\mathrm{pm}}\right)$ and/or performance index $\left(\mathrm{P}_{\mathrm{pk}}\right.$ or $\left.\mathrm{P}_{\mathrm{pm}}\right)$, in order to meet certain output specifications (e.g. customer requirements, specifications, or engineering tolerances).

- An organisational (workforce) capability can be described in terms of the skills and knowledge possessed by an operator or team of operators to perform a task or series of tasks within certain human performance parameters, expressed as his/her/their physical, sensorial and cognitive abilities - based on classifiers, in order to meet certain output specifications (e.g. rate of errors, speed of work).

- A financial investment capability can be described in terms of the willingness to invest and the financial instruments (resources) available in a manufacturing firm to invest in a project, expressed as financial investment ratios, in order to finance such (production innovation) project (e.g. ROI, IRR and MARR).

SA/Step 3. Describe necessary new production (manufacturing) and organisational (workforce) capabilities to support the production innovation's project objectives (TO-BE model):

- New expected production (manufacturing) capability expressed as improved customer experience and responsiveness (on-time delivery, manufacturing cycle time, time to make changeovers), improved quality (yield, customer rejects), improving efficiency (throughput, capacity utilisation, equipment effectiveness, schedule or production attainment), reduced inventory (WIP inventory/turns), ensured compliance (reportable health, safety and environmental incidents, number of non-compliance events/year), reduced maintenance (\% planned vs. emergency maintenance work orders, operation downtime), increased flexibility (rate of new product introduction, engineering change order cycle time), reduced costs and increased productivity (total manufacturing cost per unit excl. materials, manufacturing cost as a $\%$ of revenue, net operating profit, productivity in revenue per employee, average unit contribution margin, return on assets, energy cost per unit, cash cycle time, EBITBA, customer fill rate/on-time delivery/perfect order \%) [5]. 
- New expected organisational (workforce) capability expressed as operators' improved physical abilities (ability to lift, walk, manipulate and assemble) together with its non-functional properties (speed, strength, precision and dexterity), improved sensorial abilities (vision, smell, sound, touch, vibration), and improved cognitive abilities (perception, memory, reasoning, decision, motor response).

- Expected financial investment capability expressed as an equal to or greater than $\mathrm{X}$ hurdle rate (cost of capital, expected returns).

SA/Step 4. Identify the gaps between the production system $A S-I S$ and $T O-B E$ models for the successes of the production innovation project:

- MOF capabilities should be compared using clear assessment parameters between the manufacturing firm's $A S-I S$ and $T O-B E$ models.

- Manufacturing firm targeted new MOF capabilities can also be benchmarked in order to validate that the production innovation project will actually deliver a competitive advantage in the market.

SA/Step 5. Start the scouting of new production technologies (e.g. production equipment and working methods), evaluating their readiness level, and assessing their integration to the production environment (shop-floor):

- For this purpose, morphological matrixes can be used as a method and tool to select the best solutions available to realise the necessary MOF capabilities for the production innovation project (see Table 4).

Table 4. MOF Capabilities Needed vs. Capabilities Enablers - Morphological Matrixes

\begin{tabular}{|c|c|c|c|}
\hline \multicolumn{4}{|c|}{ Manufacturing Capability vs. Manufacturing Technology Morphological Matrix } \\
\hline $\begin{array}{c}\text { Production } \\
\text { Capability Needed } \\
\end{array}$ & $\begin{array}{c}\text { Manufacturing } \\
\text { Technology } 1 \\
\end{array}$ & $\begin{array}{l}\text { Manufacturing } \\
\text { Technology } 2\end{array}$ & $\begin{array}{l}\text { Manufacturing } \\
\text { Technology \# }\end{array}$ \\
\hline Capability 1 & MTRL 9 & MTRL 4 & MTRL 6 \\
\hline Capability 2 & MTRL 5 & MTRL 8 & MTRL 7 \\
\hline Capability \# & MTRL 3 & MTRL 1 & MTRL 10 \\
\hline \multicolumn{4}{|c|}{ Organisational Capability vs. Working Method Morphological Matrix } \\
\hline $\begin{array}{c}\text { Organisational } \\
\text { Capability Needed }\end{array}$ & $\begin{array}{l}\text { Working } \\
\text { Method } 1\end{array}$ & $\begin{array}{l}\text { Working } \\
\text { Method } 2\end{array}$ & $\begin{array}{l}\text { Working } \\
\text { Method \# }\end{array}$ \\
\hline Capability 1 & WMRL 5 & WMRL 4 & WMRL 9 \\
\hline Capability 2 & WMRL 4 & WMRL 8 & WMRL 6 \\
\hline Capability \# & WMRL 10 & WMRL 3 & WMRL 4 \\
\hline \multicolumn{4}{|c|}{ Financial Investment Capability vs. Financial Plan Morphological Matrix } \\
\hline $\begin{array}{c}\text { Financial Investment } \\
\text { Capability Needed }\end{array}$ & $\begin{array}{c}\text { Financial } \\
\text { Plan } 1\end{array}$ & $\begin{array}{l}\text { Financial } \\
\text { Plan } 2 \\
\end{array}$ & $\begin{array}{c}\text { Financial } \\
\text { Plan \# }\end{array}$ \\
\hline Capability 1 & FIRL 4 & FIRL 10 & FIRL 7 \\
\hline Capability 2 & FIRL 9 & FIRL 7 & FIRL 3 \\
\hline Capability \# & FIRL 6 & FIRL 5 & FIRL 9 \\
\hline
\end{tabular}

SF/Step 6. Define the production equipment to be acquired (based on a make/buy study) and the training plan for the workforce as well as its financing schema (as a project): 
- Activities to be conducted include assessing production feasibility, estimating manufacturing costs, defining manufacturing processes and their tooling, and beginning the training of the workforce.

SF/Step 7. Conduct the installation and set-up of the new production equipment as well as start training the workforce:

- Activities to be conducted include evaluating early production output and beginning operation of the new production system.

SI/Step 8. Ramp-up the new production equipment (the production system):

- Activities to be conducted include the gradual and continuous transition from the production ramp-up to ongoing production, working out any remaining human and/or machine problem in the production process.

SI/Step 9. Mature production operations until achieving regular production capability and capacity aimed.

- Activities to be conducted include the gradual and continuous improvement of the production performance and process(es) standardisation in order to increase efficiency.

\section{Conclusions}

In this paper, it is argued that production innovation is a 'socio-technical endeavour' that requires alignment of readiness levels of manufacturing technology, organisational (workforce) learning and financial investment capabilities to enable new manufacturing competence in a firm. Moreover, 'enabling' new manufacturing competences does not imply an instant competitive advantage for the firm, since newly acquired competence will need to mature and to be mastered, in order to transform it into 'true' competitive advantage. The presented research work has contributed with a proposal for strategizing for production innovation, based on a framework of readiness and maturity levels. This proposal include a step-by-step guide for production managers and/or engineers to implement a strategy for production innovation.

\section{References}

1. Larsson, L.: Characteristics of Production Innovation. Licentiate Thesis. Luleå University of Technology (2017)

2. Utterback, J.M., Abernathy, W.J.: A Dynamic Model of Process and Product Innovation. The Int. Journal of Management Science, Pergamon Press, 3:6, pp. 639-656 (1975)

3. Peters, S.: A Readiness Level Model for New Manufacturing Technologies. Prod. Eng. Res. Devel., 9, pp. 647-654 (2015)

4. Sauser, B., Gove, R., Forbes, E., Ramirez-Marquez, J.E.: Integration Maturity Metrics: Development of an Integration Readiness Level. Information, Knowledge, Systems Management, 9, pp.17-46 (2010)

5. Davidson, M.: 28 Manufacturing Metrics that Actually Matter (The Ones We Rely On). http://blog.lnsresearch.com/blog/bid/188295/28-manufacturing-metrics-that-actuallymatter-the-ones-we-rely-on (2013) 